DOI: $10.19195 / 0137-1134.107 .1$

\author{
MARTA DE BAZELAIRE DE RUPPIERRE* \\ Uniwersytet Łódzki
}

\title{
PRAWO DO PRYWATNOŚCI OSÓB PRAWNYCH PODCZAS KONTROLI PRZEDSIĘBIORSTWA DOKONYWANEJ PRZEZ KOMISJĘ EUROPEJSKĄ
}

\author{
WSTĘP
}

Komisja Europejska (dalej: Komisja lub KE) wydaje rocznie kilkanaście decyzji w przedmiocie niedozwolonych praktyk antykonkurencyjnych ${ }^{1}$. Wydaje się to niedużo, jednak, zważywszy na skalę dochodzeń i ewentualne kary finansowe nakładane na podmioty ${ }^{2}$, warto zwrócić uwagę na mechanizm ochrony praw podstawowych osób prawnych. Nieodłącznym elementem postępowania w przedmiocie naruszenia reguł konkurencji jest niezapowiedziana kontrola w siedzibie przedsiębiorstwa. Ten efektywny środek pozyskiwania materiału dowodowego z natury swojej pozostaje w kolizji z prawem do prywatności wyrażonym w art. 7 Karty Praw Podstawowych ${ }^{3}$ (dalej: Karta lub KPP), w szczególności zasadą nienaruszalności miru domowego oraz tajemnicy korespondencji. Niniejszy artykuł ma na celu porównanie standardu ochrony przewidzianego w art. 8 Konwencji o Ochronie Praw Człowieka i Podstawowych Wolności (dalej: konwencja lub EKPC) ${ }^{4}$ oraz

* Doktorant w Katedrze Europejskiego Prawa Konstytucyjnego WPiA UŁ.

1 Zob. Roczne sprawozdanie z działalności Komisji Europejskiej, dostępne: http://ec.europa. eu/competition/publications/annual_report/2015/fw_pl.pdf (dostęp: 27.10.2016).

2 Np. Apple - 13 mld euro kary, Microsoft - $561 \mathrm{mln}$ euro kary, Otis - $225 \mathrm{mln}$ euro kary.

3 Karta Praw Podstawowych Unii Europejskiej (2007/C 303/01) z dnia 14 grudnia 2007 r., OJ C 326, 26 października 2012 r., s. 391-407.

${ }^{4}$ Konwencja o Ochronie Praw Człowieka i Podstawowych Wolności sporządzona w Rzymie dnia 4 listopada 1950 r., zmieniona następnie Protokołami nr 3, 5 i 8 oraz uzupełniona Protokołem nr 2, Dz.U. 1993 Nr 61, poz. 284; art. 8 EKPC: „1. Każdy ma prawo do poszanowania swojego życia prywatnego i rodzinnego, swojego mieszkania i swojej korespondencji. 2. Niedopuszczalna jest ingerencja władzy publicznej w korzystanie z tego prawa z wyjątkiem przypadków przewidzianych przez ustawę i koniecznych w demokratycznym społeczeństwie z uwagi na bezpieczeństwo państwowe, bezpieczeństwo publiczne lub dobrobyt gospodarczy kraju, ochronę porządku i zapobieganie przestępstwom, ochronę zdrowia i moralności lub ochronę praw i wolności osób". 
w art. $7 \mathrm{Kpp},{ }^{5}$ przy uwzględnieniu obowiązku zgodnej wykładni Karty z konwencją, której poziom ochrony przyjmowany jest za minimalny. Na przykładzie prawa do prywatności zaobserwować można zarówno dialog sędziowski między Europejskim Trybunałem Praw Człowieka (dalej: Trybunał w Strasburgu lub ETPC) a Trybunałem Sprawiedliwości UE (dalej: TSUE lub Trybunał w Luksemburgu), jak też jego brak.

\section{NIEZAPOWIEDZIANE KONTROLE PRZEPROWADZANE PRZEZ KOMISJĘ EUROPEJSKĄ}

Komisja Europejska rozporządzeniem Rady (WE) nr 1/2003 z dnia 16 grudnia 2002 r. w sprawie wprowadzenia w życie reguł konkurencji ustanowionych w art. 81 i 82 Traktatu (dalej: rozporządzeniem 1/2003) ${ }^{6}$ uzyskała instrumenty umożliwiające sprawowanie kontroli nad przestrzeganiem zasad ustanowionych w art. 101 i art. 102 Traktatu o Funkcjonowaniu Unii Europejskiej ${ }^{7}$. W szczególności art. 20 rozporządzenia 1/2003 wyposaża ją w prawo dokonywania niezapowiedzianych kontroli przedsiębiorstw tzw. down raids, które przeprowadzane są przez urzędników Komisji ${ }^{8}$ po okazaniu pisemnego upoważnienia. W ramach przeprowadzanych czynności inspektorzy uprawnieni są do: a) wejścia do wszelkich pomieszczeń lub środków transportu przedsiębiorstwa, b) sprawdzenia ksiąg i innych rejestrów, c) pobrania kopii i wyciągów z tych ksiąg, d) pieczętowania pomieszczeń, ksiąg i rejestrów, d) zadawania pracownikom przedsiębiorstwa i ich przedstawicielom pytań dotyczących przedmiotu postępowania9 ${ }^{9}$. Efekt zaskoczenia umożliwia zebranie kluczowych dowodów, co zwiększa szansę na wykrycie niedozwolonych praktyk i nałożenie kar finansowych na przedsiębiorstwo $^{10}$. Rzecznik Generalny, Juliane Kokott, podkreśla jednak, że ,już samo doświadczenie inspekcji należy zaliczyć do przerażających, gdy o porannych godzinach przed drzwiami siedziby przedsiębiorstwa pojawiają się inspektorzy

5 Art. 7 KPP: „Każdy ma prawo do poszanowania życia prywatnego i rodzinnego, domu i komunikowania się".

${ }^{6}$ Rozporządzenie Rady (WE) nr 1/2003 z dnia 16 grudnia 2002 r. w sprawie wprowadzenia w życie reguł konkurencji ustanowionych w art. 81 i 82 Traktatu, Polskie wydanie specjalne: rozdział 08 , t. 002, s. $205-229$.

7 Wersja skonsolidowana Traktatu o funkcjonowaniu Unii Europejskiej, Dz.U. C 202 z 7 czerwca 2016 r., s. $1-388$.

${ }^{8}$ Lub inne upoważnione do tych czynności osoby.

9 A. Jurkowska-Gomułka, T. Skoczny, Wspólne reguły konkurencji Unii Europejskiej, Warszawa 2010, s. 24-101.

${ }^{10}$ M. Michałek, The Right to Defence in EU Competition Law: The case of inspections, Warszawa 2015, s. 181; zob. również M. Michałek-Gervais, Granice zakresu uprawnień kontrolnych Komisji Europejskiej w świetle najnowszego orzecznictwa TSUE, ,iKAR” 2015, nr 8 (4), s. 25. 
Komisji Europejskiej z zamiarem przeprowadzenia kontroli, aby ustalić, czy przedsiębiorstwo to uwikłane jest w antykonkurencyjne machinacje"11. Szeroki zakres kompetencji Komisji łączący funkcje dochodzeniowe, wykonawcze i orzecznicze służy przede wszystkim ochronie konkurencyjności wspólnego rynku $^{12}$, jednak wskutek takiej niespodziewanej wizyty dochodzi zazwyczaj do kolizji z prawami podstawowymi przedsiębiorców - do prywatności lub do obrony $^{13}$. Rodzi to obawy, czy w ramach unijnych postępowań antymonopolowych, szczególnie w przypadku niezapowiedzianych kontroli, zapewnione są należyte gwarancje procesowe chroniące jednostki przed nieproporcjonalnymi i arbitralnymi działaniami instytucji.

Problem ten został dostrzeżony przez unijnego prawodawcę, który w preambule do rozporządzenia 1/2003 zobowiązał Komisję do poszanowania prawa do obrony przedsiębiorców w prowadzonych postępowaniach oraz wskazał, że rozporządzenie respektuje podstawowe prawa i uznaje zasady przyjęte w Karcie Praw Podstawowych Unii Europejskiej. Rozporządzenie 1/2003 powinno być również odpowiednio interpretowane i stosowane zgodnie z tymi zasadami i prawami ${ }^{14}$. Do czasu wejścia w życie Traktatu z Lizbony Karta Praw Podstawowych nie była aktem wiążącym prawnie, jednak w doktrynie pojawiły się koncepcje o „samozwiązaniu się” Kartą przez instytucje ją proklamujące (Radę UE, Parlament Europejski oraz Komisję). Charakter Karty sprzed ponownej proklamacji jest wprawdzie sporny, lecz część autorów uznaje ją za porozumienie międzyinstytucjonalne ${ }^{15}$, czyli instrument współpracy między organami UE lub wyrażania wspólnego stanowiska na zewnątrz w ważnych sprawach. Karta jest zatem wiążąca dla zawierających ją instytucji, które dokonując „samozwiązania się”,

11 Opinia z dnia 3 kwietnia 2014 r. Nexans, C-37/13P, ECLI:EU:C:2014:223, pkt. 1-2.

12 K. Kowalik-Bańczyk, Problematyka ochrony praw podstawowych w unijnych postepowaniach $w$ sprawach z zakresu ochrony konkurencji, Warszawa 2010, s. 7-9.

13 Prawo do obrony zdefiniować można jako: „kompleksową, podstawową zasadę prawną wyposażającą każdą osobę (fizyczną bądź prawną), na której sytuację prawną wpływ miała jednostronna decyzja władzy, w jurydyczne prawo do ochrony swojego uprawnionego interesu, przejawiające się poprzez podtrzymywanie lub kwestionowanie roszczenia skierowanego przez tę osobę lub przeciwko niej” [tłum. własne]. Zob. M. Michałek, op. cit., s. 53. Lub, jak proponuje K. Kowalik-Bańczyk, jako „zakreśloną w orzecznictwie TSUE zasadę procesową stanowiącą wytyczną dla organu prowadzącego postępowanie antymonopolowe, by pozwolić stronie postępowania na czynny udział w tym postępowaniu, w sposób pozwalający na obronę racji tego przedsiębiorstwa". Zob. K. Kowalik-Bańczyk, Prawo do obrony w unijnych postępowaniach antymonopolowych. W kierunku unifikacji standardów proceduralnych w Unii Europejskiej, Warszawa 2012, s. 78.

14 Pkt 5 i pkt 37 rozporządzenia 1/2003.

15 Traktat z Lizbony po raz pierwszy wyraźnie wymienia porozumienia międzyinstytucjonalne, mimo że były one zawierane pod rządami poprzednich Traktatów (np. porozumienie w sprawie dyscypliny budżetowej i należnego zarządzania finansami z 2006 r. 2006/C 139/01). Obecnie stanowią formalne akty, które mogą mieć charakter wiążący, a którymi posługują się instytucje do realizacji swoich kompetencji. Zob. więcej w: A. Wyrozumska, Pojęcie prawa UE i jego źródła, [w:] J. Barcz, M. Górka, A. Wyrozumska, Instytucje i prawo Unii Europejskiej, Warszawa 2015, s. 244. 
pozwalają podmiotom zewnętrznym przewidzieć, jak organy te będą postępować w przyszłości. Instytucje te uznały, że są zobowiązane do przestrzegania postanowień Kpp przy wykonywaniu swoich kompetencji, w szczególności: w procesie stanowienia lub stosowania prawa, w kontaktach wzajemnych, w stosunkach z państwami członkowskimi i jednostkami, a także w relacjach z państwami trzecimi ${ }^{16}$. Z tą koncepcją współgra wypowiedź Romano Prodiego (ówczesnego przewodniczącego KE), który w swoim wystąpieniu wygłoszonym dnia 7 grudnia 2000 roku oświadczył, że dla Komisji uroczysta proklamacja Karty stanowi zobowiązanie instytucji do jej przestrzegania we wszystkich działaniach Unii. Sama Karta stanowi narzędzie do weryfikowania poszanowania praw podstawowych przez Wspólnotę przy wykonywaniu jej uprawnień. Pokreślił również, że każdy obywatel może być pewien, iż Komisja będzie respektować postanowienia Karty we wszystkich aspektach życia Unii ${ }^{17}$. Do wypowiedzi Romano Prodiego oraz do punktu 37 preambuły odniosła się następnie Rzecznik Generalny Juliane Kokott, stwierdzając, że przy prowadzeniu postępowań antymonopolowych należy uwzględniać postanowienia Karty Praw Podstawowych, gdyż Komisja w drodze uroczystego aktu sama z własnej inicjatywy zobowiązała się do jej przestrzegania. Zdaniem Rzecznik w postępowaniach prowadzonych przez Komisję po 7 grudnia 2000 roku wiążące zastosowanie ma Karta. Natomiast w sprawach, które miały miejsce przed datą proklamacji, Karta nie wywołuje wprawdzie skutków porównywalnych z tymi przewidzianymi w prawie pierwotnym, jednak jako źródło poznania prawa stanowi informację o prawach podstawowych zagwarantowanych w prawie wspólnotowym ${ }^{18}$. Do 2009 roku w sprawach z zakresu prawa konkurencji Trybunał nie powołał się bezpośrednio na $\mathrm{Kpp}^{19}$, nawet gdy wprost stanowiło

16 K. Kowalik-Bańczyk, Problematyka ochrony praw..., s. 46-47; S. Biernat, Źródła prawa Unii Europejskiej, [w:] Prawo Unii Europejskiej. Zagadnienia systemowe, prawo materialne i polityki, red. J. Barcz, Warszawa 2006, s. 196-197. Podobnie: E. Dubout, The Protection of Fundamental Rights and the Allocation of Competences in the EU: A Clash of Constitutional Logics, [w:] The Question of Competence in the European Union, red. L. Azoulai, Oxford 2014, s. 197. Odmienne stanowisko przedstawił Cezary Mik, który uznał Kartę za uroczystą deklarację międzyinstytucjonalną, niemającą mocy prawnie wiążącej nawet w stosunkach między instytucjami, a będącą wyrazem intencji politycznych. C. Mik, Europejskie Prawo Wspólnotowe, Warszawa 2000, s. 525; zob. więcej F. Jasiński, Karta Praw Podstawowych Unii Europejskiej, Warszawa 2003, s. 294-295.

17 Wystąpienie Romano Prodiego wygłoszone dnia 7 grudnia 2000 r. w Nicei.

18 Opinia z dnia 8 grudnia 2005 r. Nederlandse Federatieve Vereniging, C-105/04P, ECLI:EU: C:2005:751, pkt. $107-108$ oraz przypis 58 .

19 Zdaniem S. Biernata TSUE nie był związany Kartą, gdyż nie był instytucją ją proklamującą lub będącą stroną porozumienia międzyinstytucjonalnego. Podnosił jednak, że Karta mogła być wykorzystywana dla interpretacji konkretnego przepisu, jako wyraz aktualnego stanowiska UE co do katalogu praw podstawowych, sposobu ich rozumienia oraz standardów ochrony. S. Biernat, op. cit., s. 197. 
to przedmiot pytania prejudycjalnego ${ }^{20}$, czynili to natomiast rzecznicy generalni ${ }^{21}$ oraz niekiedy $\mathrm{Sacd}^{22}$.

Wraz z wejściem w życie Traktatu z Lizbony Karta Praw Podstawowych UE uzyskała moc prawną taką jak Traktaty, stając się częścią prawa pierwotnego, mającą zastosowanie do instytucji, organów i jednostek organizacyjnych Unii przy poszanowaniu zasady pomocniczości oraz do Państw Członkowskich w zakresie, w jakim stosują one prawo Unii ${ }^{23}$. Uzyskanie przez Kartę mocy wiążącej pozbawiało kontrowersji stwierdzenie, że podczas kontroli Komisja zobowiązana jest do respektowania postanowień Kpp, w tym art. 41 Karty (prawo do dobrej administracji), art. 7 Karty (prawo do prywatności) czy art. 47 Karty (prawo do skutecznego środka prawnego i dostępu do bezstronnego sądu) i art. 48 Karty (domniemanie niewinności i prawo do obrony) ${ }^{24}$.

\section{PRAWO DO PRYWATNOŚCI PRZEDSIĘBIORCY PODCZAS NIEZAPOWIEDZIANYCH KONTROLI}

Wykonywanie uprawnień KE w zakresie kontroli stanowi niewątpliwie znaczącą ingerencję w strefę prawną przedsiębiorcy, w szczególności tajemnicę korespondencji czy nienaruszalność miru domowego. Artykuł 7 Karty stanowi, że „każdy ma prawo do poszanowania życia prywatnego i rodzinnego, domu i komunikowania się". Zgodnie z Wyjaśnieniami ${ }^{25}$ prawo do prywatności wyrażone w Karcie odpowiada gwarancjom (rights which correspond - art. 52 ust. 3$)^{26}$

20 Wyrok z dnia 12 maja 2005 r. ERSA, C-347/03, ECLI:EU:C:2005:285.

21 Np. Opinia z dnia 8 grudnia 2005 r. Nederlandse Federatieve Vereniging, C-105/04P, ECLI: EU:C:2005:751, pkt 59: „KPP musi być brana pod uwagę w postępowaniach kartelowych”.

22 Wyrok z dnia 12 lipca 2007 r. w sprawie T-474/04 Pergan Hilfsstoffe für industrielle Prozesse przeciwko Komisji, ECLI:EU:T:2007:306, pkt. 75-77; wyrok z dnia 5 kwietnia 2006 r. w sprawie T-279/02 Degusasa AG przeciwko Komisji, ECLI:EU:T:2006:103, pkt 115. Zob. więcej K. Kowalik-Bańczyk, Problematyka ochrony praw..., s. 48; F. Jasiński, op. cit., s. 228-235.

${ }^{23}$ Zob. art. 6 TUE oraz art. 51 ust. 1 KPP oraz Deklaracja w sprawie Karty praw podstawowych Unii Europejskiej stanowiąca załącznik do Traktatu z Lizbony; Karta została wskazana również jako pisane źródło prawa administracyjnego o tej samej randze co zasady ogólne prawa UE. Zob. H.C.H. Hofmann, G.C. Rowe, A.H. Türk, Administrative Law and Policy of the European Union, Oxford 2011, s. 73.

${ }^{24}$ K. Kowalik-Bańczyk, Problematyka ochrony praw..., s. 47; M. Szpunar, Kilka uwag systematyzujacych na temat zakresu zastosowania Karty Praw Podstawowych UE, „Europejski Przegląd Sądowy" 2015, nr 10, s. 5.

${ }^{25}$ Wyjaśnienie dotyczące Karty Praw Podstawowych (2007/C 303/02), Dz.U.UE C 303/17 z dnia 14 grudnia 2007, s. 20.

26 Art. 52 ust. 3 KPP: ,3. W zakresie, w jakim niniejsza Karta zawiera prawa, które odpowiadają prawom zagwarantowanym w europejskiej Konwencji o ochronie praw człowieka i podstawowych wolności, ich znaczenie i zakres są takie same jak praw przyznanych przez tę konwencję. Niniejsze postanowienie nie stanowi przeszkody, aby prawo Unii przyznawało szerszą ochronę". 
zapewnionym przez art. 8 EKPC, w związku z czym art. 7 Kpp powinien być interpretowany zgodnie z konwencją, a poziom ochrony nie może być niższy niż ten wyznaczony przez EKPC. Karta jako integralna część prawa pierwotnego UE może przyznać wyższy poziom ochrony niż ten przewidziany w konwencji, czyli nadać danemu prawu szersze znaczenie lub zakres ${ }^{27}$. Artykuł $53 \mathrm{Kpp}$ zakazuje dokonywania takiej wykładni postanowień Karty, która prowadziłaby do ograniczenia lub naruszenia praw człowieka i podstawowych wolności uznanych i gwarantowanych przez umowy międzynarodowe, w szczególności EKPC oraz przez konstytucje państw członkowskich $\mathrm{UE}^{28}$, a w konsekwencji dopuszczałaby obniżenie standardu ochrony.

Kryteriami dopuszczalności ingerencji w prawo poszanowania życia prywatnego są uregulowanie jej w „ustawie” oraz niezbędność do ochrony wymienionych w art. 8 ust. 2 Konwencji wartości w demokratycznym społeczeństwie ${ }^{29}$. Zgodnie $\mathrm{z}$ art. 52 ust. $3 \mathrm{Kpp}$ takie same przesłanki mają zastosowanie do oceny zasadności naruszenia art. $7 \mathrm{Kpp}$. Zasada proporcjonalności, stanowiąca ogólną zasadę prawa UE, ma na celu racjonalne zbadanie, czy dany środek prawny lub administracyjny jest odpowiedni i konieczny do uzyskania zakładanego celu. Zwyczajowo przyjmuje się, że zasada ta składa się z trzech testów: odpowiedniości, niezbędności oraz proporcjonalności sensu stricto. Najpierw bada się, czy przyjęty środek jest adekwatny do uzyskania przewidzianego rezultatu. Następnie, czy konieczny jest do osiągnięcia celu, którego nie sposób osiągnąć za pomocą innego działania. Test proporcjonalności sensu stricto zakłada natomiast wyważenie interesów stron oraz uwzględnienie, że przyjęty środek nie może być nadmiernie uciążliwy ${ }^{30}$.

W przypadku kontroli osób fizycznych powszechną praktyką jest uzyskanie uprzedniego upoważnienia sądowego na przeprowadzenie inspekcji, jednak już w wyroku Société Colas Est Trybunał wskazywał, że w przypadku osób prawnych ingerencja władz w ich prawa może być dalej idąca ${ }^{31}$. Odmienny standard ochrony osób prawnych i fizycznych został również potwierdzony w wyroku TSUE Volker

27 A. Wróbel, O niektórych problemach sądowego stosowania Karty Praw Podstawowych, [w:] Karta Praw Podstawowych w europejskim i krajowym porzadku prawnym, red. A. Wróbel, Warszawa 2009, s. 99; idem, Tytut VII. Postanowienia Ogólne dotyczace wykładni i stosowania Karty, [w:] Karta Praw Podstawowych Unii Europejskiej. Komentarz, red. A. Wróbel, Warszawa 2013, s. 1368-1369.

28 M. Wąsek-Wiaderek, Ochrona praw oskarżonego w Karcie Praw Podstawowych UE nowy standard czy zatwierdzenie status quo?, „Europejski Przegląd Sądowy” 2015, nr 10, s. 17-18.

29 G. Materna, Warunki podejmowania kontroli i przeszukań w postępowaniach z zakresu ochrony konkurencji prowadzonych na podstawie ustawy o ochronie konkurencji i konsumentów $w$ aspekcie orzecznictwa na tle art. 8 ETPCz, „iKAR” 2015, nr 8 (4), s. 10.

30 Zob.więcej T.-I. Harbo, The Function of the Proportionality Principle in EU Law, ,European Law Journal" 16 (2), 2010, s. 165.

31 Wyrok ETPC z dnia 16 kwietnia 2002 r. Société Colas Est przeciwko Francji, nr 37971/97, pkt. 48-49; zob. również postanowienie ETPC z dnia 20 listopada 2012 r. Debut zrt i inni przeciwko Węgrom, nr 24851/10, pkt 3. 
und Markus Schecke ${ }^{32}$, w którym to Trybunał podniósł, że ingerencja w sferę praw osób prawnych może być uznana za proporcjonalną i uzasadnioną, w sytuacjach gdy identyczne działanie skierowane względem osób fizycznych stanowiłaby naruszenie Karty. Niezależnie jednak od tej generalnej oceny niezbędność ingerencji jest oceniana ad casum, w szczególności analizuje się proporcjonalność nakładanych na jednostkę obowiązków i ograniczeń do realizowanego celu ${ }^{33}$.

\section{NIENARUSZALNOŚĆ „MIRU DOMOWEGO”}

Europejski Trybunał Praw Człowieka, powołując się na szeroką interpretację określeń ,życie prywatne” oraz „mieszkanie”, uznał, że ochrona wynikająca z art. 8 EKPC może dotyczyć również działalności zawodowej osób fizycznych ${ }^{34}$. W sprawie Niemietz ${ }^{35}$ Trybunał wyjaśniał, że „działalność, która dotyczy zawodu lub prowadzenia interesów może równie dobrze być prowadzona w prywatnej rezydencji, a działalność która nie jest z tym związana, może równie dobrze być prowadzona w prowadzona w biurze lub w pomieszczeniach handlowych". W przełomowej sprawie Société Colas Est ${ }^{36}$ ETPC potwierdził, że ochrona gwarantowana przez art. 8 konwencji rozciąga się na osoby prawne, ich siedziby oraz pomieszczenia ${ }^{37}$. Uznał, że nie ma powodu, aby termin ,życie prywatne” wyłączał działalność o zawodowym lub biznesowym charakterze, szczególnie gdy w wielu przypadkach te dwie sfery życia są ze sobą powiązane i się przenikają, a cel, jakim jest zapobieżenie arbitralnej ingerencji władz, jest wspólny ${ }^{38}$. Taka interpretacja nie narusza prerogatyw państw-stron, gdyż nadal, po spełnieniu przesłanek z art. 8 ust. 2 EKPC, ingerencja jest dopuszczalna, a nawet w przypadku osób prawnych może być ona dalej idąca ${ }^{39}$. Z tego względu zakrojone na szeroką

32 Wyrok z dnia 9 listopada 2010 r. Volker und Markus Schecke, C92/09 i C93/09, ECLI:EU:C:2010:662, pkt 87.

33 Wyrok ETPC z dnia 21 grudnia 2010 r. Société Canal Plus i inni przeciwko Francji, nr 29408/08, pkt 54; wyrok ETPC z dnia 2 listopada 2014 r. Delta Pekárny a.s. przeciwko Republice Czeskiej, nr 97/11, pkt 82.

34 M.A. Nowicki, Wokół Konwencji Europejskiej. Komentarz do Europejskiej Konwencji Praw Człowieka, Warszawa 2013, s. 728.

35 Wyrok ETPC z dnia 16 grudnia 1992 r. Niemietz przeciwko Niemcom, 13710/88, pkt 30; K. Kowalik-Bańczyk, Prawo do obrony..., s. 398.

36 Wyrok ETPC z dnia 16 kwietnia 2002 r. Société Colas Est przeciwko Francji, nr 37971/97, pkt 41.

37 Ibidem; zob. również: wyrok ETPC z dnia 28 kwietnia 2004 r. Buck przeciwko Niemcom, nr 41604/98, pkt 31; wyrok ETPC z dnia 28 lipca 2007 r. Association for European Integration and Human Rights and Ekimdzhiev przeciwko Bułgarii, nr 62540/00, pkt 60.

38 Wyrok ETPC z dnia 16 grudnia 1992 r. Niemietz przeciwko Niemcom, 13710/88, pkt 29; zob. więcej K. Kowalik-Bańczyk, Prawo do obrony..., s. 398-399.

39 Wyrok ETPC z dnia 16 grudnia 1992 r. Niemietz przeciwko Niemcom, 13710/88, pkt 30-31. 
skalę przeszukania w siedzibie przedsiębiorstwa przeprowadzane przez organy administracji są dopuszczalne z uwagi na ryzyko pominięcia lub ukrycia dowodów świadczących na niekorzyść przedsiębiorcy. Musi mieć on jednak zapewnione skuteczne i adekwatne gwarancje przeciwko nadużyciom ${ }^{40}$. Jeżeli odpowiednie środki ochrony nie zostały zapewnione, prowadzone przeszukiwanie nie może być uznane za proporcjonalne w stosunku do celu, jakiemu służy ${ }^{41}$. Choć art. 8 EKPC sformułowany jest jako przepis materialny, to implicite wynika z niego nakaz dochowania rzetelnej procedury gwarantującej ochronę interesów jednostki. Ocena musi obejmować całość procedury, zwłaszcza politykę, podjęte decyzje, stopień uwzględnienia interesów osób zainteresowanych oraz przewidziane gwarancje proceduralne. Podstawą decyzji muszą być wyczerpujące i sprawdzalne dane dotyczące wszystkich aspektów sprawy ${ }^{42}$.

Wyrok Société Colas Est doprowadził do zmiany praktyki TSUE, który we wcześniejszym wyroku Hoechst ${ }^{43}$ odrzucił możliwość stosowania art. 8 EKPC do siedziby przedsiębiorstwa. Trybunał w swoim późniejszym orzeczeniu Roquette Frères $^{44}$ uznał, że prawo do prywatności i gwarancje z niego wynikające mają zastosowanie do czynności organów państwowych lub unijnych, które podejmują działania na terenie przedsiębiorstwa, i bez znaczenia jest fakt, iż przedsiębiorca jest osobą prawną. Powyższe założenia zostały potwierdzone w wyroku Nexans z 2014 roku $^{45}$, w którym Trybunał potwierdził, że „,W odniesieniu do uzasadnionego charakteru planowanej ingerencji i zakresu obowiązku współpracy przedsiębiorstw należy zaznaczyć, że wymóg ochrony przed arbitralnymi lub dysproporcjonalnymi ingerencjami władzy publicznej w sferę prywatnej działalności osoby, zarówno fizycznej, jak i prawnej, stanowi ogólną zasadę prawa Unii. Zasada ta została ustanowiona $\mathrm{w}$ art. 7 Karty, zgodnie z którym $»[\mathrm{k}] \mathrm{ażdy}$ ma prawo do poszanowania życia prywatnego i rodzinnego, domu i komunikowania się«"46.

40 Wyrok ETPC z dnia 16 kwietnia 2002 r. Société Colas Est przeciwko Francji, nr 37971/97, pkt 41-48.

41 Wyrok ETPC z dnia 16 kwietnia 2002 r. Société Colas Est przeciwko Francji, nr 37971/97, pkt 48-49.

42 L. Garlicki, art. 8, [w:] Konwencja o Ochronie Praw Człowieka i Podstawowych Wolności, tom I, Komentarz do artykułów 1-18, red. L. Garlicki, Warszawa 2010, s. 492; M.A. Nowicki, Wokót Konwencji Europejskiej. Komentarz do Europejskiej Konwencji Praw Człowieka, Warszawa 2013, s. 674.

43 Wyrok z dnia 21 września 1989 r. Hoechst, 46/87 oraz 227/88, ECLI:EU:C:1989:337, pkt $17-19$.

44 Wyrok z dnia 22 października 2002 r. Roquette Frères, C-94/00, ECLI:EU:C:2002:603, pkt 29.

45 Wyrok z dnia 14 października 2014 r. w sprawie T-135/09 Nexans France SAS i Nexans SA przeciwko Komisji, ECLI:EU:T:2012:596, pkt 40.

46 Zob. więcej: J. Vedsted-Hansen, Art 7-Private Life, Home and Communication, [w:] The EU Charter of Funadmental Rights. A Commentary, red. S. Peers, T. Hervey, J. Kenner, A. Ward, Oxford-Portland 2014, s. 158-159. 
Modyfikacja linii orzeczniczej TSUE umożliwia postawienie tezy o ochronie osób prawnych oraz ich siedzib na mocy art. 8 EKPC oraz art. $7 \mathrm{Kpp}^{47}$.

Trybunał w Strasburgu w wyroku Delta Pekárny ${ }^{48}$ stwierdził, że w odniesieniu do osób prawnych uprzednia zgoda sądu na dokonanie inspekcji nie jest wymagana, o ile przeprowadzenie niezapowiedzianej kontroli (i) miało oparcie w przepisach prawa, (ii) kontrola była przeprowadzona w uzasadnionym celu oraz (iii) była konieczna ${ }^{49}$. Gwarancją odpowiedniej ochrony przed nadużyciami jest dodatkowo istnienie systemu kontroli sądowej, w ramach której sąd bada legalność oraz konieczność nałożenia dotkliwego środka. W przypadku osób prawnych wystarczy, by kontrola ta była następcza (ex post facto), jednak, aby została uznana za skuteczną, musi zapewniać realną ochronę przed działaniami władzy. Nie jest wystarczające, by sąd krajowy jedynie formalnie przeprowadził badanie legalności aktu (czy organ miał prawo wydać decyzję), a konieczne jest przede wszystkim zbadanie okoliczności faktycznych sprawy (fr. éléments de fait), które skłoniły organ antymonopolowy do przeprowadzenia inspekcji. W przeciwnym wypadku nie można uznać, by działania władzy publicznej były poddane skutecznej kontroli sądowej, nawet w trybie następczym ${ }^{50}$.

Zgodnie $\mathrm{z}$ art. 20 rozporządzenia 1/2003 do zainicjowania kontroli wystarczające jest, aby Komisja podejrzewała przedsiębiorstwo o posiadanie istotnych dla niej informacji, a decyzja ta nie podlega kontroli sądowej ex ante. W sprawie Deutsche Bahn ${ }^{51}$ skarżący, podnosząc naruszenie art. 7 Kpp i art. 8 EKPC, powoływał się m.in. na wyrok Delta Pekárny oraz wskazywał na obowiązek Komisji uzyskania uprzedniej zgody Sądu lub sądu krajowego na przeprowadzenie inspekcji. Trybunał przypomniał jednak, że ze względu na odmienny standard ochrony osób fizycznych i prawnych brak uprzedniego zezwolenia sądu stanowi tylko jeden z elementów analizowanych w kontekście naruszenia powołanych norm. Konieczne jest przy tym uwzględnienie wszystkich czynników prawnych i faktycznych konkretnej sprawy, w tym zakresu uprawnień organów, okoliczności ingerencji oraz istniejących gwarancji proceduralnych, zwłaszcza możliwości dokonania odpowiedniej następczej kontroli sądowej. Gwarancje te obejmują: (i) uzasadnienie decyzji w sprawie inspekcji; (ii) nałożenie na Komisję ograniczeń w trakcie przeprowadzania inspekcji; (iii) niemożność narzucenia inspekcji przy użyciu środków przymusu przez Komisję; (iv) możliwość interwencji organów krajowych oraz (v)

47 Zob. więcej K. Kowalik-Bańczyk, Prawo do obrony..., s. 397-402.

48 Wyrok ETPC z dnia 2 listopada 2014 r. Delta Pekárny a.s. przeciwko Republice Czeskiej, nr 97/11, pkt 82.

49 B. Turno, E. Wardęga, Uprzednia i następcza kontrola aktów upoważniających organ ochrony konkurencji do przeprowadzenia niezapowiedzianej kontroli (przeszukania) przedsiębiorcy. Glosa do wyroku Europejskiego Trybunału Praw Człowieka z 2 października 2014 r. w sprawie Delta Pekárny przeciwko Republice Czeskiej, ,iKAR”2015, nr 8(4), s. 110.

50 Ibidem, s. 111-112. Zob. więcej G. Materna, op. cit., s. 12-14.

51 Wyrok z dnia 6 września 2013 r. Deutsche Bahn, C-583/13 P, ECLI:EU:C:2015:404, pkt $18-37$. 
istnienie środków zaskarżenia a posteriori ${ }^{52}$. Trybunał zaznaczył przy tym, że istnienie następczej kontroli sądowej, która obejmuje zarówno kwestie prawne, jak i faktyczne, umożliwia właściwe zrekompensowanie braku uprzedniej zgody sądu. Przedsiębiorca może wnieść odwołanie natychmiast po doręczeniu mu decyzji o inspekcji. Dodatkowo posiada gwarancję, że Komisja nie będzie mogła wykorzystać zebranych informacji, jeśli okaże się, że zostały one pozyskane z naruszeniem prawa ${ }^{53}$. Co interesujące, Rzecznik Generalny Niels Wahl w swojej opinii do sprawy Deustche Bahn zwrócił uwagę, że wprawdzie Karta mogłaby przewidywać wyższy standard ochrony niż konwencja (zgodnie z art. 52 ust. 3 Karty), jednak w żadnym wypadku nie dostrzega ani w prawie pierwotnym, ani w prawie w tórnym Unii elementu, który mógłby prowadzić do takiego wniosku ${ }^{54}$. Pokazuje to, że Trybunał, stosując Kartę Praw Podstawowych, powiela standard ochrony wypracowany przez ETPC, nie dążąc do jego zwiększenia. Można rzec, że w tym zakresie odrzuca swoją potencjalnie prekursorską rolę w promowaniu praw podstawowych w Unii.

\section{TAJEMNICA KORESPONDENCJI}

Prawo do poszanowania korespondencji na gruncie konwencyjnym oraz unijnym obejmuje wszelkie formy technicznego przekazywania wiadomości, a szczególne znaczenie ma możliwość swobodnych kontaktów z prawnikiem na każdym etapie postępowania ${ }^{55}$. Z pewnym niedopowiedzeniem wiąże się natomiast kwestia tajemnicy korespondencji osób prawnych. Trybunał Praw Człowieka w swoich wyrokach Robathin ${ }^{56}$ i Vinci $^{57}$ wprost stwierdza, że dane elektroniczne i wszystkie dokumenty zajęte podczas kontroli podlegają ochronie przewidzianej w art. 8 EKPC. Przy ocenie dopuszczalności zajęcia korespondencji przez inspektorów badane jest prawo oraz praktyka organów antymonopolowych w kontekście zapewnienia przedsiębiorcy wystarczających możliwości oponowania przeciwko arbitralnej lub nadmiernej ingerencji ${ }^{58}$.

52 K. Manteuffel, Zakaz fishing expeditions w toku kontroli Komisji Europejskiej. Glosa do wyroku Trybunału Sprawiedliwości Unii Europejskiej z dnia 18 czerwca 2015 r. w sprawie C-583/13 P Deutsche Bahn AG i inni przeciwko Komisji, ,iKAR” 2015, nr 8 (4), s. 120.

53 M. Michałek, op. cit., s. 200.

54 Opinia z dnia 12 lutego 2015 r. Deutsche Bahn, C583/13P, ECLI:EU:C:2015:92, pkt 41.

55 J. Sobczak, Tytut II. Wolności, Artykut 7, [w:] Karta Praw Podstawowych Unii Europejskiej..., s. 257; M.A. Nowicki, op. cit., s. 734, 739.

56 Wyrok ETPC z dnia 3 lipca 2012 r. Robathin przeciwko Austrii, nr 30457/06, pkt 39.

57 Wyrok ETPC z dnia 2 kwietnia 2015 r. Vinci Construction et GTM Génie Civil et Services przeciwko Francji, nr 63629/10 i 60567/10, pkt 63.

58 Wyrok ETPC z dnia 2 kwietnia 2015 r. Vinci Construction..., pkt 66. 
Na podstawie art. 20 ust. 2 lit. b i c rozporządzenia 1/2003 oraz z związku z pkt. $9-10$ oraz pkt 14 Noty Wyjaśniającej z dnia 11 września 2015 r. ${ }^{59}$ Komisja podczas inspekcji ma prawo do zbadania wszelkich ksiąg handlowych i dokumentów, w tym również danych elektronicznych, twardych dysków oraz kont e-mail pracowników. Informacje te mogą być zabezpieczone i skopiowane, a dalsze ich przeszukiwanie może być prowadzone poza siedzibą przedsiębiorstwa. Inspektorzy Komisji skwapliwie korzystają z przysługujących im uprawnień, zajmując całe twarde dyski przeszukiwanych komputerów. Mimo podnoszonego w skargach problemu nadmiernego i nieproporcjonalnego zajmowania danych ${ }^{60}$, TSUE nie wypowiedział się, czy powołane dokumenty objęte są prawem do tajemnicy korespondencji zawartym $\mathrm{w}$ art. $7 \mathrm{Kpp}$. Teoretycznie, zgodnie z art. 52 ust. $3 \mathrm{Kpp}$ w zw. z art. $53 \mathrm{Kpp}$, oczywistym byłoby zastosowanie standardu przewidzianego w EKPC. Niestety TSUE pomija zarzuty skarżących, nie odnosi się do działań Komisji, podkreślając jednocześnie konieczność zapewnienia efektywności unijnym kontrolom ${ }^{61}$. Pasywność Trybunału prowadzi do braku jednoznacznej spójności między standardem konwencyjnym $\mathrm{i}$ unijnym w zakresie ochrony tajemnicy korespondencji osób prawnych, przy czym EKPC prima facie oferuje jeszcze większą ochronę.

W wyroku Vinci ETPC ponownie podkreślił, że skuteczna i efektywna kontrola działań administracji przez organy sądowe jest konieczna w świetle art. 8 EKPC. Przedsiębiorca, gdy nie ma możliwości omówienia zasadności zajęcia lub sprawdzenia treści dokumentów podlegających zatrzymaniu, nie może się efektywnie sprzeciwić przejęciu dokumentów objętych prawniczą tajemnicą zawodową (tzw. przywilejem prawniczym, ang. legal professional privilidge) ${ }^{62}$ czy też tych pozostających bez związku ze sprawą. $Z$ tego względu przedsiębiorca powinien mieć możliwość przeprowadzenia kontroli legalności działań organu antymonopolowego, chociażby ex post. Sędzia, który zostanie wyznaczony do zbadania zarzutów skarżącego dotyczących zajęcia dokumentów niezwiązanych z dochodzeniem lub objętych tajemnicą zawodową, zobowiązany jest (po uprzedniej szczegółowej analizie oraz przeprowadzeniu testu proporcjonalności) do orzeczenia o dalszym losie tychże dokumentów. W razie potrzeby winien zarządzić ich zwrot. Nie wystarczy bowiem jedynie zbadanie legalności samej czynności bez wnikania, w jakich

59 Dostępna: http://ec.europa.eu/competition/antitrust/legislation/explanatory_note.pdf (dostęp: 27.10.2016).

${ }^{60}$ Np. wyrok z dnia 14 października 2014 r. w sprawie T-135/09 Nexans France SAS i Nexans SA przeciwko Komisji, ECLI:EU:T:2012:596, pkt 129-158.

61 M. Michałek, op. cit., s. 210.

62 Przywilej prawniczy (tajemnica adwokacka) różni się w zależności od państwa członkowskiego, ale można go zdefiniować jako obowiązek prawnika do zachowania w tajemnicy informacji przekazanych przez klienta $\mathrm{w}$ ramach relacji prawnik-klient oraz gwarancję klienta, że udzielone informacje oraz porady prawne nie będą ujawniane. Przywilej ten stosuje się do prowadzonej korespondencji. Zob. więcej D. van Gerven, Professional secrecy in Europe, [w:] The Bar of Brussels (compiled), Professional Secrecy of Lawyers in Europe, Cambridge 2013, s. 2-3. 
okolicznościach i w jakim zakresie przeprowadzane były działania organu administracji ${ }^{63}$. Należy również nadmienić, że orzecznictwo ETPC uznaje, iż całość dokumentów przedsiębiorcy oraz całość korespondencji z prawnikiem objęta jest ochroną art. 8 EKPC. Bez znaczenia pozostaje, czy wymiana informacji prowadzona była z prawnikiem wewnętrznym przedsiębiorstwa (ang. in-house lawyer), czy też z prawnikiem zewnętrznym wobec klienta, $\mathrm{tj}$. adwokatem, radcą prawnym lub doradcą niepozostającym w stosunku pracy z przedsiębiorcą ${ }^{64}$.

Na gruncie prawa UE sytuacja ulega pewnej komplikacji, gdyż inne podejście prezentowane jest w stosunku do dokumentów objętych tajemnicą zawodową niż tych, które zostały zebrane przypadkowo lub są niezwiązane ze sprawą ${ }^{65}$. Zapewnienie poufności w komunikacji między prawnikiem a jego klientem zostało uznane za ogólną zasadę prawa unijnego, jednak dotyczy wyłącznie kontaktów z „niezależnym prawnikiem”, które prowadzone są w celu „obrony” klienta. Ochroną nie są zatem objęte dokumenty, które powstały w ramach współpracy z prawnikiem wewnętrznym (ang. in-house lawyer), a jedynie te stworzone w relacji klient-niezależnie działający pełnomocnik (ang. a consultant lawyer) ${ }^{66}$. Już na tej płaszczyźnie widać, że zakres ochrony przyznany w systemie UE jest węższy niż ten przewidziany w konwencji. Podczas inspekcji przedsiębiorca może się sprzeciwić okazaniu dokumentów objętych przywilejem prawniczym, oczywiście po uprzednim uargumentowaniu swojego stanowiska. W tym momencie otwierają się dwie opcje postępowania. Pierwszą jest umieszczenie spornego dokumentu w zapieczętowanej kopercie i przekazanie urzędnikowi Komisji, który po przeprowadzeniu spotkania wyjaśniającego dokona oceny zasadności odmowy. W drugiej sytuacji, w przypadku nieskorzystania z procedury „zapieczętowanej koperty”, Komisja może wydać decyzję nakazującą okazanie dokumentu, od której na mocy art. 263 TFUE przysługuje odwołanie. Wówczas to Sąd bada, czy wskazany dokument jest chroniony przywilejem, czy też nie ${ }^{67}$.

Należy nadmienić, że możliwość złożenia skargi na działanie Komisji z tytułu zajęcia dokumentów objętych tajemnicą zawodową stanowi wyjątek od ogólnej zasady, zgodnie z którą środki przyjęte przez Komisję podczas inspekcji nie stanowią zaskarżalnych decyzji per se, a jedynie służą wykonywaniu decyzji zarządzającej przeszukanie ${ }^{68}$. Oznacza to, że brak jest odrębnej kontroli sądowej w przypadku zajęcia danych, także tych elektronicznych, które niezwiązane są z przedmio-

63 Wyrok ETPC z dnia 2 kwietnia 2015 r. Vinci Construction..., pkt 74-80.

${ }^{64}$ K. Kowalik-Bańczyk, Prawo do obrony..., s. 390.

65 Rozważania te są również istotne w kontekście art. $47 \mathrm{Kpp}$.

${ }^{66}$ K. Kowalik-Bańczyk, Prawo do obrony..., s. 392, D. van Gerven, op. cit., s. 12-13, 21; wyrok z dnia 18 maja 1982 r. AM \& S, 155/79, ECLI:EU:C:1982:157, pkt 21-24; wyrok z dnia 12 grudnia 1991 r. w sprawie T-30/89 Hilti, przeciwko Komisji, ECLI:EU:T:1991:70, pkt 11; wyrok z dnia 17 września 2007 r. w sprawach połączonych T-125/03 i T-253/03 Akzo Nobel przeciwko Komisji, ECLI:EU:T:2007:287, pkt 166-169.

67 K. Kowalik-Bańczyk, Prawo do obrony..., s. 393-394; D. van Gerven, op. cit., s. 21.

68 M. Michałek, op. cit., s. 269. 
tem dochodzenia. Czynność taka może być zaskarżona wyłącznie wraz z decyzją kończącą postępowanie lub nakładającą sankcje z tytułu utrudniania współpracy. Jeśli żadna z tych decyzji nie zostanie wydana lub minie wiele lat do czasu jej podjęcia, przedsiębiorca nie ma możliwości zaskarżenia działań Komisji, które de facto nie podlegają kontroli sądowej ${ }^{69}$. Co więcej, biorąc pod uwagę praktykę Komisji w nakładaniu dotkliwych sankcji finansowych przy każdej próbie obstrukcji postępowania, wątpliwe jest uznanie, by przedsiębiorcom przysługiwało realne prawo sprzeciwu ${ }^{70}$.

Nawet jeżeli Sąd lub Trybunał na podstawie art. 263 TFUE stwierdziłby nieważność decyzji Komisji ${ }^{71}$, to zgodnie z art. 266 TFUE nie jest kompetentny do wskazania w wyroku sposobu jego wykonania, gdyż wybór właściwych środków przysługuje organowi, który wydał zaskarżony akt ${ }^{72}$. Komisja zobowiązana jest do podjęcia kroków koniecznych do usunięcia skutków naruszenia prawa, co w przypadku decyzji uprzednio wykonanych oznaczać może przywrócenie stanu sprzed wydania aktu (restitutio in integrum), czyli np. zwrotu zajętych dokumentów. Niemniej jednak Trybunał Sprawiedliwości, związany postanowieniami traktatów, nie może uczynić zadość wymogom EKPC i nakazać Komisji podjęcia konkretnych działań.

Podsumowując, zgodnie z orzecznictwem ETPC zajęcie wszelkich dokumentów osób prawnych podlega pełnej kontroli następczej oraz musi spełniać wymogi zawarte w art. 8 ust. 2 EKPC. Sąd musi być również władny do orzekania o dalszym losie dokumentów, w tym zarządzenia ich zwrotu. Przede wszystkim ETPC postuluje, aby przedsiębiorcy mieli zagwarantowany dostęp do skutecznego mechanizmu odwołania się od decyzji organu w przedmiocie zatrzymanych danych objętych tajemnicą zawodową lub będących poza zakresem dochodzenia ${ }^{73}$. Natomiast w ramach prawa UE (i) regulacja dotycząca dokumentów objętych przywilejem prawniczym jest bardziej restrykcyjna niż ta wynikająca z orzecznictwa ETPC oraz (ii) brak jest jakichkolwiek zasad chroniących przedsiębiorcę przed zajęciem informacji niezwiązanych z dochodzeniem, w tym możliwości bezpośredniego odwołania się od czynności Komisji. Taki stan rzeczy niezgodny jest $\mathrm{z}$ art. $7 \mathrm{w}$ rozumieniu art. 52 ust. $3 \mathrm{Kpp}$ oraz art. $53 \mathrm{Kpp}$, gdyż wprowadza niższy standard ochrony osób prawnych przed arbitralnymi działaniami władz.

69 Ibidem, s. 208.

70 Zob. np. wyrok z dnia 26 listopada 2014 r. w sprawie T-272/12 Energeticky a prumyslovy, ECLI:EU:T:2014:995.

71 Decyzji nakazującej okazanie dokumentów objętych przywilejem prawniczym, decyzji nakładającej sankcję na przedsiębiorstwo z tytułu utrudniania współpracy lub decyzji kończącej postępowanie.

72 M. Jaśkowski, Sądowa kontrola legalności aktów administracyjnych Unii Europejskiej, Warszawa 2016, s. 263.

73 C. Rawnsley, Vinci Construction e.a. v France: Limits on Unannounced Inspections on the Basis of the Rights to a Fair Trial and to the Respect for Privacy, „Journal of European Competition Law \& Practice" 6 (7), 2015, s. 493. 
Najprostszym rozwiązaniem byłoby oczywiście uwzględnienie przez Trybunał Sprawiedliwości dotychczasowych wyroków ETPC, w tym uznanie zaskarżalności wszystkich czynności Komisji przeprowadzanych podczas inspekcji, nie tylko decyzji o zajęciu dokumentów objętych przywilejem prawniczym w wąskim jego rozumieniu. Również Komisja, jako związana postanowieniami Karty (art. 51 ust. $1 \mathrm{Kpp}$ ), mogłaby zmodyfikować swoją politykę w zakresie zbierania materiału dowodowego. Natomiast spełnienie warunku, zgodnie z którym TSUE posiadałby kompetencje do wydania KE wiążącej dyspozycji — zwrotu dokumentów zajętych z naruszeniem art. $7 \mathrm{Kpp}$, wymagałoby rewizji traktatów.

\section{ZAKOŃCZENIE}

Jak zauważa Robert Grzeszczak, TSUE od kilku lat buduje linię orzeczniczą praw podstawowych na podstawie Karty, umiejscawiając ją w samym centrum unijnego porządku konstytucyjnego. Statystyki świadczą o rosnącej liczbie odwołań w wyrokach Trybunału do Karty przy jednoczesnym coraz rzadszym odnoszeniu się do konwencji. Takie działanie ma umożliwić Trybunałowi rozwijanie linii orzeczniczej bezpośrednio na tle Kpp i w efekcie doprowadzić do określenia poziomu ochrony, który uwzględniać będzie specyfikę i autonomię prawa $\mathrm{UE}^{74}$. Czy jednak Trybunał wykorzystuje ten potencjał?

Biorąc pod uwagę sposób stosowania Karty Praw Podstawowych przez Trybunał Sprawiedliwości, nie sposób oprzeć się wrażeniu, że w sprawach z zakresu prawa konkurencji jest to instrument wykorzystywany rzadko i w sytuacjach, w których Europejski Trybunał Praw Człowieka wypracował już linię orzeczniczą $^{75}$. O ile o jednolitym standardzie ochrony można mówić w przypadku zasady nienaruszalności miru domowego, to przestrzeganie tajemnicy korespondencji na gruncie prawa UE nie odpowiada standardom konwencyjnym. Problemem jest zarówno zakres stosowania art. $7 \mathrm{Kpp}$, jak i brak skutecznych środków ochrony sądowej. Trybunał w Luksemburgu, zasłaniając się dobrem postępowania i koniecznością zapewniania efektywności kontroli, unika wydawania wyroków, które zawężałyby kompetencje dochodzeniowe Komisji lub rozwiewały wątpliwości praktyki i doktryny ${ }^{76}$. Jako nadrzędny cel stawiana jest ochrona konkurencyjności wspólnego rynku.

Trybunał nie dąży również do wykorzystania klauzuli z art. 52 ust. $3 \mathrm{Kpp}$ umożliwiającej zapewnienie wyższego standardu ochrony niż tego wynikającego z konwencji. Natomiast i tak ambitnym celem wydaje się zapewnienie standardu

74 R. Grzeszczak, A. Szmigielski, Sądowe stosowanie Karty Praw Podstawowych UE w odniesieniu do państw członkowskich — refleksje na podstawie orzecznictwa Trybunału Sprawiedliwości i praktyki sądów krajowych, „Europejski Przegląd Sądowy” 10, 2015, s. 11-12.

75 Por. wyrok Delta Pekárny z wyrokiem Deutsche Bahn.

$76 \mathrm{~Np}$. w zakresie tajemnicy korespondencji. 
EKPC w postępowaniach z zakresu prawa konkurencji, mimo że TSUE oraz KE są do tego zobligowane na mocy art. 53 Kpp. Można odnieść wrażenie, że przy wszystkich deklaracjach rozwoju praw podstawowych oraz rosnącym znaczeniu Karty Praw Podstawowych gwarancje dla przedsiębiorców znajdują się na peryferiach tych postulatów i są celowo marginalizowane.

\section{THE RIGHT TO PRIVACY OF LEGAL PERSONS DURING THE EUROPEAN COMMISSION'S INSPECTIONS}

\section{Summary}

The paper aims to discuss the application of the Charter of Fundamental Rights by the EU institutions in competition law proceedings, showing as an example the respect for the right to privacy of undertakings during the inspections carried out by the European Commission. Although exercising the control powers of the Commission potentially collides with a number of fundamental rights expressed in the Charter, it is the analysis of Art. 7 CFR that allows to depict the evolution of the EU's approach to privacy of legal persons, showing the accompanying judicial dialogue, or lack thereof, between the European Court of Human Rights and the Court of Justice of the EU. The article short-defines the dawn raids, examines the application of Article 7 CFR to legal persons, highlighting the aspects of protection of domicile and secrecy of correspondence, compares the standards provided by ECHR and EU law, pondering also on how the CFR guarantees can be provided and effectively controlled. It also reflects on the issue whether the Court of Justice has a forerunner role in promoting fundamental rights of undertakings in matters of competition law. 